\title{
Editorial: Natural gas
}

\section{William J. Nuttall}

Department of Engineering and Innovation, The Open University, Milton Keynes, UK

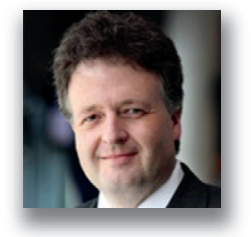

Within the global energy system natural gas is extremely important. It is core to an industry that has, and is, undergoing dramatic change. These developments deserve more scholarly research and it was with such an awareness that this themed issue has been assembled. Technological change associated with natural gas is politically contentious and occasionally highly charged. The Editorial Advisory Board of the journal, noting the multiple changes in economics, technology and politics surrounding the subject, came to the conclusion that natural gas merited special attention. This themed issue of the journal is the result.

In this themed issue we do not seek to provide a comprehensive review of historical developments relating to natural gas. Rather, from the start it has been our intention to focus on the present and to look ahead to the future.

Our approach was to issue a call for papers stressing the following possible topics for potential inclusion.

- Scenarios for global gas production and demand.

- What next for liquefied natural gas (LNG)?

- Natural gas and transport applications (including compressed natural gas (CNG), LNG and gas to liquids).

- Natural gas heating - technology and policy issues.

- Natural gas innovations and new technologies.

- The green credentials of natural gas (including carbon capture and storage).

- Natural gas use - prospects for radical innovations.

- Natural gas and energy security.

- Natural gas as a chemical feedstock.

- The future of hydraulic fracturing-known as 'fracking'.

While it is not possible within the space of a single themed issue to consider all the interesting and timely aspects shaping the future for natural gas, through the various papers presented here, insight is indeed given into several of the challenges alluded to above.

This themed issue stresses two particular sets of issues. In a contemporary and short-term context we consider European natural gas supply including the need to understand better issues surrounding shale gas extraction. Looking further ahead we give particular emphasis to one possible area of technological innovation concerning synergies with hydrogen production, distribution and use.
In order to appreciate issues shaping the future of European natural gas supply it is helpful to provide some opening comment concerning European energy policy and economics.

At its heart energy policy seeks to balance three major goals

(i) economic goals concerning affordability and national competitiveness

(ii) environmental goals, especially concerning greenhouse gas $(\mathrm{GHG})$ emissions reductions

(iii) energy security goals spanning primary energy resources, energy conversion capacity and energy system reliability.

While it is arguably trivial to meet one goal and relatively straightforward to meet two, the task of simultaneously meeting all three is extremely challenging. The experience of the last 20 years might suggest that it verges on being impossible.

The second goal, motivated primarily by a concern for anthropogenic climate change, has received much policy prominence in the European Union in recent years. Arguably, however, the other two goals (economics and security) are of more direct saliency to energy users and even to politicians. These realities have given rise to a mismatch between what Europe says it will do in the area of environmental goals and what Europe is actually doing in seeking to address all three policy goals simultaneously. The rhetoric points to aspirations for dramatic reductions in GHG emissions by mid-century, by way of improvements in efficiency, a rise in electrification and a switch to ultra-lowcarbon power generation (especially from renewable sources). [In the UK long-term dramatic GHG emissions reduction is arguably more than just rhetoric, noting the statutory power of the Climate Change Act 2008 (2008). That said, however, in the UK parliament is said to be sovereign and as such any Act can be subject to later repeal or modification. The risk of such repeal is real if the calls for change can be sufficiently powerful to attract parliamentary (and most especially government) attention.] The reality, however, is a European energy system that is only managing to achieve modest GHG emissions improvements and the main contributors to the modest success achieved have arguably arisen independent of climate-led energy policy. Such independent developments include: the transformation of the industrial base in central and eastern Europe since the fall of communism, the liberalisation of European electricity markets and the major global economic downturn in the years since 2008. 
Germany has sought to position itself as a leader in energy matters, giving prominence to its Energiewende, or 'energy transition'. The emerging German reality, however, is an energy system noteworthy for its visible of use of renewables and its less visible use of coal and lignite (Figure 1). The energy mix in Germany is arguably a product of politics stressing the ecological and anti-nuclear concerns of affluent westerners against the interests of economically-deprived coal mining communities in eastern Germany. The consequence is a system that is seemingly no lower in GHG emissions than a system that could be based upon natural gas alone.

Germany, of course, has given much thought over the years to the role of natural gas and its strategy has largely been based on large-scale long-term contracts with Russian companies, such as Gazprom. A strategy of contracts with trusted partners is different in vision to one based on a strong belief in the merits of global natural gas market liberalisation (i.e. privatisation, but most importantly with competition). The latter approach has been the one promoted by the United Kingdom.

Within the European Union the British have long stressed the beneficial role of markets. UK gas security has been a story of a transition from indigenous production to global commerce increasingly based on LNG imports. The market-led strategy was developed between 1990 and 2010 until it became clear that liberalised markets were incapable of building an ultralow-carbon electricity future based on renewables and most especially nuclear power. British concern for environmental

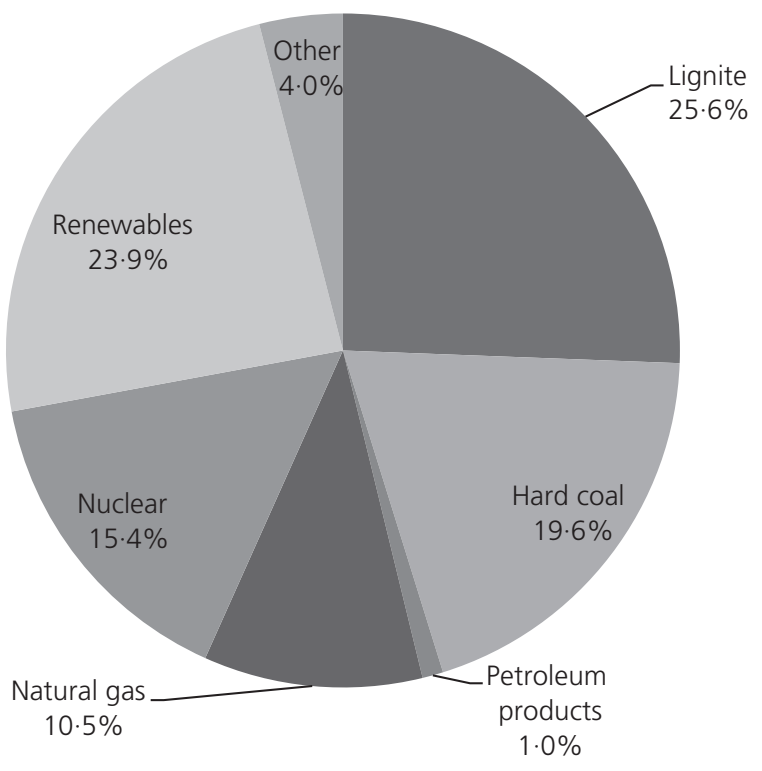

Figure 1. German gross electricity generation 2013 (data source: AG Energiebilanzen (Auer and Anatolitis (2014)) goals has led the country down a different path from Germany-one that remains open to nuclear power. With some irony, it is now the British who seek EU approval for long-term (and even subsidised) contracts for the construction of new nuclear power plants.

In the UK there appears to have been some tension within the current coalition government (2010-2015) between those who see much merit in natural gas as a moderately low-carbon fuel easily able to support the integration of intermittent renewables and those who resist an increased role for the fuel given its merely moderately low-carbon credentials (Clark et al., 2013). Carbon capture and storage technologies have, thus far, failed to contribute to bridging the gap between these two positions. Stated briefly, UK policy sees a greater role for nuclear power and a lower role for coal than is seen in German energy policy. Both countries seek a growing role for renewables, although the German scale of ambition is bolder. It is in connection with natural gas that subtle and interesting differences of vision apply. Much of the difference between these visions for the European energy future relates to market design and the nature of natural gas supply contracts. Underpinning such strategic choices lies the reality of the need for infrastructure expansion and the potential for technological change.

In this themed issue we have four papers that help us understand better the current and future situation concerning natural gas supply in Europe. Oluwabamise Olanrewaju and co-authors provide an overview of the European natural gas supply system and assess the vulnerability of the EU to natural gas supply disruptions, especially those relating to a reduction in Ukrainian transit capacity (Olanrewaju et al., 2015). The authors highlight the risk of unmet demand in south-east Europe. Improved local gas storage could militate against such risks, but long-term attention needs to be given to improved and diversified import infrastructures.

Nikola Vištika and co-authors provide a detailed examination of short-term issues shaping one south-east European natural gas market-Croatia (Vištika et al., 2015). They illustrate the benefits to be obtained from artificial neural network models applied to the day-ahead and intraday balancing of the Croatian gas market. These attributes are assessed in different seasonal contexts, as temperature is a major determinant of gas demand. The authors demonstrate the efficiency of artificial neural network-based approaches, but also point to the important benefits that would arise from a smarter and better metered gas supply system.

Tatiana Mitrova and co-authors provide powerful insight into the European natural gas market from a Russian perspective (Mitrova et al., 2015). They examine the options facing Russia and Russian entities in the future and observe that 
long-standing and historically successful approaches may not be appropriate going forward. The authors provide an introduction to some highly topical and important issues facing the European energy system in 2015. Historically, Russian gas contracts have involved significant indexing to the oil price, but the oil price has fallen significantly in recent months and it is far from clear what the future will hold in that regard. Other changes, such as relating to LNG regasification and pipeline infrastructures, will also favour, or disfavour, various Russian strategies. These issues are most ably introduced by Mitrova and her colleagues.

Ciaran McAleenan and co-authors introduce and explain hydraulic fracturing or 'fracking' as a technique to extract natural gas (and oil) from areas surrounded by otherwise impermeable shale rock (McAleenan et al., 2015). The technique has been known for many decades having first been deployed commercially in the United States in the 1940s (Montgomery and Smith, 2010). It is only in the last 10 years, however, that fracking has transformed the north American energy scene. In such a short period the US has moved from plans imagining large-scale LNG imports to ones imagining large-scale exports (Vukmanovic et al., 2013).

McAleenan et al. (2015) show the potential importance of shale gas to the United Kingdom, but also introduce societal and environmental concerns. In Europe, several EU member states have policies blocking developments in fracking-the $\mathrm{UK}$ is therefore a noteworthy exception to this EU trend. The influential and independent European Group on Ethics in Science and Technology, which reports directly to the President of the European Commission, has expressed reservations about fracking technology (Kinderlerer, 2013).

The last two papers in this themed issue look to the longerterm future and posit the potential synergistic benefits to be obtained between natural gas technologies and a future hydrogen economy, or economies. Of course this is just one of many forward-looking approaches deserving attention. We are pleased to highlight it here, as it is one that has received less prominence in the literature than some others.

Natural gas has long been a source of hydrogen for industrial process applications. Typically, methane steam reforming yields hydrogen, but with the release of harmful carbon dioxide emissions. Emma Hanley and co-authors point to a range of synergies between today's natural gas technologies and emerging prospects for hydrogen commercialisation (Hanley et al., 2015). A range of current, and future, natural gas to hydrogen production methods is introduced and the potential for hydrogen as a clean energy carrier is explained. The special attributes of cryogenic liquid hydrogen are also stressed.
Liang-Chih Ma and co-authors write from the United States to provide insight into the advantages to be obtained in methane steam reforming by way of a move to catalytic membrane reactor modules (Ma et al., 2015). This approach yields higher efficiencies and provides carbon dioxide at high pressure, thereby facilitating sequestration and avoiding harmful emissions to the atmosphere.

We hope that this themed issue demonstrates that there are indeed beneficial synergies to be obtained between natural gas and another economically storable, but zero direct in-use GHG emission energy carrier, hydrogen.

In closing, as editor of this themed issue, I would like to thank all the authors of the papers featured here; the anonymous referees who kindly provided peer review; and the current and past staff of the Institution of Civil Engineers who provided much support in assembling this publication. Special thanks are due to Sarah Brown at ICE for all her wise advice and assistance.

Finally, perhaps the issues of concern to us are best summed up by the words of former US Department of Energy head, Bill Richardson, when he said in 2012, "Natural gas is the future. It is here" (Campanile, 2012).

\section{REFERENCES}

Auer J and Anatolitis V (2014) The Changing Energy Mix in Germany. Deutsche Bank Research, Frankfurt am Main, Germany. See https://www.dbresearch.com/PROD/DBR_ INTERNET_EN-PROD/PROD0000000000337663/The +changing+energy+mix + in + Germany $\% 3 \mathrm{~A}+$ The + drivers + ar.PDF (accessed 22/02/2015).

Campanile C (2012) It's a fracker-jack idea: ex-energy big. New York Post, 23 August. See http://nypost.com/2012/08/ 23/its-a-fracker-jack-idea-ex-energy-big/ (accessed 28/06/ 2014).

Clark P, Pickard J and Rigby E (2013) Osborne and Davey poised to clash over green energy targets. Financial Times, 3 October. See http://www.ft.com/cms/s/0/5ba550b8-2c1711e3-8b20-00144feab7de.html (accessed 28/02/2014).

Climate Change Act 2008 (2008) Elizabeth II. Chapter 27. Her Majesty's Stationery Office, London, UK.

Hanley ES, Glowacki BA, Nuttall WJ and Kazantzis N (2015) Natural gas - synergies with hydrogen. Proceedings of the Institution of Civil Engineers - Energy 168(1): 46-59, http://dx.doi.org/10.1680/ener.14.00018.

Kinderlerer J (2013) An Ethical Framework for Assessing Research, Production and Use of Energy, Opinion 27. European Group on Ethics in Science and New Technologies, European Commission, Brussels, Belgium. See http://www.eesc.europa.eu/resources/docs/105-juliankinderlerer---bepa-ethics-energy.pdf (accessed 26/02/2015). 
Ma LC, Kazantzis NK and Ma YH (2015) Natural gas in hydrogen production: a cost study. Proceedings of the Institution of Civil Engineers - Energy 168(1): 60-72, http://dx.doi.org/10.1680/ener.14.000.17.

McAleenan C, Weatherup R, Bogle G and McAleenan P (2015) Shale gas extraction - the case for a multi-disciplinary study. Proceedings of the Institution of Civil Engineers Energy 168(1): 40-45, http://dx.doi.org/10.1680/ener.14. 00022.

Mitrova T, Kulagin V and Galkina A (2015) The transformation of Russia's gas export policy in Europe. Proceedings of the Institution of Civil Engineers - Energy 168(1): 29-39, http://dx.doi.org/10.1680/ener.14.00019.

Montgomery CT and Smith MB (2010) Hydraulic fracturing: history of an enduring technology. Journal of Petroleum Technology 63(12): 26-32. See http://www.ourenergypolicy.
org/wp-content/uploads/2013/07/Hydraulic.pdf (accessed 28/06/2014).

Olanrewaju O, Chaudry M, Qadrdan M, Wu J and Jenkins N (2015) Vulnerability assessment of the European natural gas supply. Proceedings of the Institution of Civil Engineers - Energy 168(1): 4-14, http://dx.doi.org/10.1680/ ener.14.00020.

Vištica N, Banovac E and Pavlović D (2015) Gas consumption forecasting: evidence from the Croatian gas market. Proceedings of the Institution of Civil Engineers - Energy 168(1): 15-28, http://dx.doi.org/10.1680/ener.14.00015. Vukmanovic O, Turner L and McAllister E (2013) Centrica to buy US natural gas in landmark deal. Reuters, 25 March. See http://uk.reuters.com/article/2013/03/25/ uk-centrica-idUKBRE92O0PT20130325 (accessed 28/06/ 2014). 